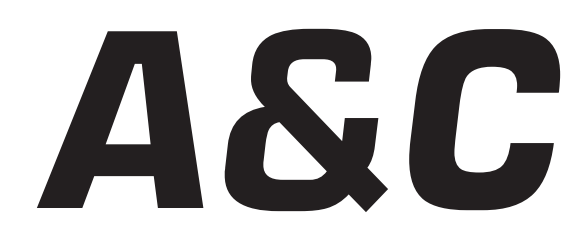

Revista de Direito Administrativo \& Constitucional

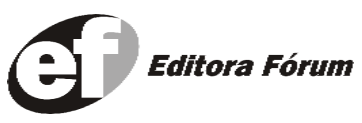

A\&C R. de Dir. Administrativo e Constitucional, Belo Horizonte, ano 5, n.19, p. 1-254, jan./mar. 2005 


\section{A\&C REVISTA DE DIREITO ADMINISTRATIVO E CONSTITUCIONAL}

\section{IPDA}

Instituto Paranaense

de Direito Administrativo

Direção Geral

Romeu Felipe Bacellar Filho

Direção Editorial

Paulo Roberto Ferreira Motta

Direção Executiva

Emerson Gabardo

Conselho de Redação

Edgar Chiuratto Guimarães

Adriana da Costa Ricardo Schier

Célio Heitor Guimarães

Conselho Editorial

Adilson Abreu Dallari

Alice Gonzáles Borges

Carlos Ari Sundfeld

Carlos Ayres Britto

Carlos Delpiazzo

Cármen Lúcia Antunes Rocha

Celso Antônio Bandeira de Mello

Clèmerson Merlin Clève

Clóvis Beznos

Enrique Silva Cimma

Eros Roberto Grau

Fabrício Motta

Guilhermo Andrés Muñoz (in memoriam)

Jaime Rodríguez-Arana Muñoz

Jorge Luís Salomoni
José Carlos Abraão
José Eduardo Martins Cardoso

José Luís Said

José Mario Serrate Paz

Juan Pablo Cajarville Peruffo

Juarez Freitas

Julio Rodolfo Comadira

Luís Enrique Chase Plate

Lúcia Valle Figueiredo

Manoel de Oliveira Franco Sobrinho

(in memoriam)

Marçal Justen Filho

Marcelo Figueiredo

Márcio Cammarosano

Maria Cristina Cesar de Oliveira
Nelson Figueiredo

Odilon Borges Junior

Pascual Caiella

Paulo Eduardo Garrido Modesto

Paulo Henrique Blasi

Paulo Neves de Carvalho (in memoriam)

Paulo Ricardo Schier

Pedro Paulo de Almeida Dutra

Regina Maria Macedo Nery Ferrari

Rogério Gesta Leal

Rolando Pantoja Bauzá

Sérgio Ferraz

Valmir Pontes Filho

Yara Stropa

Weida Zancaner

\footnotetext{
A246 A\&C Revista de Direito Administrativo e Constitucional. ano 3, n. 11, jan./mar. 2003. Belo Horizonte: Fórum, 2003.

Trimestral

ano 1, n.1, 1999 até ano 2, n.10, 2002 publicada pela Editora Juruá em Curitiba

ISSN: 1516-3210

1. Direito Administrativo. 2. Direito Constitucional. I. Fórum.
}

CDD: 342 CDU: 33.342

(c) Editora Fórum Ltda. 2005

Todos os direitos reservados. É proibida a reprodução total ou parcial, de qualquer forma ou por qualquer meio eletrônico ou mecânico, inclusive através de processos xerográficos, de fotocópias ou de gravação, sem permissão por escrito do possuidor dos direitos de cópias (Lei $n^{\circ}$ 9.610, de 19.02.1998).

Editora Fórum Ltda

Av. Afonso Pena, 2770 - 15\%16ªndar - Funcionários

CEP 30130-007 - Belo Horizonte/MG - Brasil

Tel.: 08007043737

Internet: www.editoraforum.com.br

e-mail: editoraforum@editoraforum.com.br
Editor responsável: Luís Cláudio Rodrigues Ferreira Projeto gráfico e diagramação: Luis Alberto Pimenta Revisora: Olga M. A. Sousa

Pesquisa jurídica: Fátima Ribeiro - OAB/MG 74868

Bibliotecária: Nilcéia Lage de Medeiros

CRB 1545/MG 6a região

Os conceitos e opiniões expressas nos trabalhos assinados são de responsabilidade exclusiva de seus autores.

Impressa no Brasil / Printed in Brazil

Distribuída em todo Território Nacional 


\title{
A Constituição e os Requisitos para a Investidura do Chefe do Ministério Público nos Estados
}

\begin{abstract}
Clèmerson Merlin Clève
Professor Titular das Faculdades de Direito da Universidade Federal do Paraná e da UniBrasil. Mestre e Doutor em Direito. Professor nos Cursos de Mestrado e Doutorado em Direito da Universidade Federal do Paraná. Procurador do Estado. Consultor e Advogado em Curitiba
\end{abstract}

Alessandra Ferreira Martins

Pesquisadora do Escritório Clèmerson Merlin Clève Advogados Associados

Sumário: 1 Introdução - 2 Procedimento de escolha do chefe do Ministério Público - 3 Sistema de freios e contrapesos - 4 Forma de escolha da chefia do Ministério Público e independência funcional - 5 O papel do chefe do executivo - 6 Defesa da Constituição e devida composição da lista tríplice - 7 Conclusão

\section{Introdução}

O especial cuidado dedicado ao Ministério Público na atual Constituição Federal trouxe renovada configuração ao processo de escolha do chefe da instituição. Cumpre, neste breve texto, considerar o processo bifásico ora vigente para a eleição e nomeação do Procurador-Geral de Justiça e as críticas que sobre ele se colocam, especialmente em face da inevitável participação do Chefe do Executivo no modelo de investidura adotado pelo Constituinte.

\section{Procedimento de escolha do chefe do Ministério Público}

A Constituição Federal de 1988 disciplina, a partir do artigo 127, o procedimento de nomeação do Procurador-Geral para o Ministério Público conforme se trate do âmbito da União ou dos Estados, Distrito Federal e Territórios.

Tratando da nomeação do Procurador-Geral de Justiça, dispõe no artigo 128:

$\S 3^{\circ}$ Os Ministérios Públicos dos Estados e o do Distrito Federal e Territórios formarão lista tríplice dentre os integrantes da carreira, na forma da lei respectiva, para escolha de seu Procurador-Geral, que será nomeado pelo Chefe do Poder Executivo, para mandato de dois anos, permitida uma recondução.

Da normativa constitucional decorre a necessária elaboração de lista composta por nomes de três integrantes do Ministério Público a ser A \& C R. de Dir. Administrativo e Constitucional, Belo Horizonte, ano 5, n. 19, p. 55-71, jan./mar. 2005 
encaminhada ao Governador do Estado para que este escolha, nos limites da lista elaborada pela instituição, aquele a ser nomeado para o cargo de Procurador-Geral de Justiça.

O procedimento de elaboração da lista tríplice é, ademais, matéria disciplinada pela Lei ${ }^{\circ} 8.625$ de 1993 que instituiu a Lei Orgânica Nacional do Ministério Público. Nesta, observa-se que deverá ser realizada eleição com voto plurinominal de todos os integrantes da carreira, donde os três mais votados comporão a lista. ${ }^{1}$ Manifesta-se, portanto, um procedimento interno no âmbito do qual a própria instituição escolhe aqueles integrantes da carreira que haverão de disputar a preferência do Chefe do Executivo para o exercício da chefia.

Após a formação da lista tríplice, segue-se um segundo momento em que o Governador acolhe um nome, sendo sua liberdade de escolha circunscrita ao universo delimitado pelos três nomes residentes na lista encaminhada pelo Ministério Público. Há aí, portanto, um processo bifásico para a nomeação do Procurador-Geral de Justiça no qual o exercício da competência do Chefe do Executivo é precedido de processo eleitoral manifestado no seio da própria instituição ministerial. ${ }^{2}$

Como em outra oportunidade tive ocasião de manifestar, tem-se que, diante da nova Constituição,

... a forma de investidura dos Procuradores Gerais (da União) ou de Justiça (nos Estados) representou significativo avanço. Antes da Constituição de 1988, os respectivos Procuradores Gerais (do MPU ou dos MPEs) constituíam cargos de provimento em comissão, razão pela qual podiam os Chefes do Poder Executivo (Federal ou Estaduais) livremente nomeá-los e demiti-los. A nova Constituição alterou radicalmente a sistemática. Por isso que, agora, o Procurador Geral da República (Chefe do Ministério Público da União) é nomeado, dentre os integrantes da carreira, pelo Presidente da República, após a aprovação de seu nome pela expressiva manifestação da maioria absoluta do Senado Federal (art. 128, parágrafo $1^{\circ}$, da C.F.). A nomeação implica o exercício de um mandato (rectius: exercício de cargo a prazo certo) de dois anos. Quanto aos Procuradores

\footnotetext{
"Art. 9 Os Ministérios Públicos dos Estados formarão lista tríplice, dentre integrantes da carreira, na forma da lei respectiva, para escolha de seu Procurador-Geral, que será nomeado pelo Chefe do Poder Executivo, para mandato de dois anos, permitida uma recondução, observado o mesmo procedimento.

$\S 1^{\circ}$ A eleição da lista far-se-á mediante voto plurinominal de todos os integrantes da carreira."

2 No Estado do Paraná, por exemplo, o procedimento de elaboração da lista tríplice obedece ao disposto na Lei Complementar no 85 de 1999, que, regulamentando normativa constitucional (Art. 116 da Constituição Estadual), estabeleceu a Lei Orgânica e Estatuto do Ministério Público do Estado do Paraná: "Art. 15 Serão incluídos na lista tríplice, em ordem decrescente, os três candidatos mais votados. Em caso de empate será incluído, sucessivamente, o candidato mais antigo na carreira, o de maior tempo de serviço público prestado ao Estado do Paraná e o mais idoso. Art. 16. O Procurador-Geral de Justiça encaminhará a lista tríplice, até o dia útil seguinte ao que a receber, ao Governador do Estado, que em quinze dias exercerá o seu direito de escolha sobre qualquer dos nomes dela constantes, submetendo-o à aprovação pela Assembléia Legislativa.".
} 
Gerais de Justiça (Chefes dos Ministérios Públicos locais), estes serão nomeados pelo Chefe do Poder Executivo, dentre os integrantes de listas tríplices formadas pelos próprios Ministérios Públicos dos Estados e do Distrito Federal e Territórios, e composta unicamente por integrantes da carreira. ${ }^{3}$

Não se discute o fato de constituir uma indiscutível conquista o procedimento para a escolha daqueles que exercerão os cargos de chefia do Ministério Público previsto na atual Constituição. A previsão anterior redundava na angustiante subordinação da instituição ministerial aos direcionamentos de um Poder Executivo autoritário. A dissonância com os anseios democráticos que rondavam a Constituinte tornou indispensável uma nova estruturação do Parquet, que veio a ser formulada a partir de várias contribuições oferecidas pela comunidade jurídica.

Vale mencionar a realização do Congresso Pontes de Miranda em 1981 para formulação da "Proposta de Constituição Democrática para o Brasil". " Já aí aparecia a participação da instituição ministerial na escolha de sua chefia, conforme dispunha o artigo 234.1 da proposta:

A chefia do Ministério Público será exercida pelo Procurador-Geral da Justiça, nomeado pelo Presidente e pelos Governadores dos Estados, entre os 3 membros mais votados em eleição de toda a classe, à qual só concorrerão aqueles com mais de 10 anos de carreira. ${ }^{5}$

Curiosamente, na mesma época em que se multiplicavam as críticas à forma de investidura e demissão dos Procuradores Gerais, manteve-se, em proposta advinda de um Congresso de "iniciativa pública e pioneira da sociedade civil pela modificação institucional do Ministério Público na futura reconstitucionalização do país", ${ }^{6}$ a nomeação, embora limitada pela prévia manifestação dos membros da instituição ministerial, pelo Chefe do Poder Executivo. Isso revela que as críticas se direcionavam mais à precariedade do cargo ligada à discricionariedade do governante ocasional do que, propriamente, a uma participação de outro órgão constitucional no processo de investidura.

É nítida a diretiva constitucional no sentido de exigir estreita colaboração entre os poderes para a composição dos cargos de chefia de

\footnotetext{
3 CLÈVE, Clèmerson Merlin. Temas de Direito Constitucional (e de Teoria do Direito). São Paulo: Acadêmica, 1993, p. 108.

4 Cf. VIANNA LOPES, Júlio Aurélio. Democracia e Cidadania: o novo Ministério Público Brasileiro. Rio de Janeiro: Lumen Juris, 2000, p. 85-88.

5 Anteprojeto - Proposta de uma Constituição Democrática para o Brasil. Porto Alegre: OAB/IARGS, 1981, p. 57.
}

A \& C R. de Dir. Administrativo e Constitucional, Belo Horizonte, ano 5, n. 19, p. 55-71, jan./mar. 2005 
determinadas instituições, dentre elas, o Ministério Público. Neste caso, participa o Poder Legislativo com a produção das regras disciplinadoras do processo seletivo, a instituição ministerial com a eleição de três membros da carreira igualmente aptos a exercer a chefia, e o Poder Executivo através da decisão voltada à escolha de um entre os candidatos para a devida nomeação. Em alguns casos a participação do Poder Legislativo no processo emerge com maior destaque. É o caso das Constituições Estaduais que subordinam a nomeação à aprovação da Assembléia Legislativa, nos moldes do modelo adotado no plano federal. ${ }^{7}$ Em que pese tal procedimento, em princípio, não desafiar maiores críticas, vem o STF entendendo ser inconstitucional o agravamento do sistema bifásico previsto na norma originária ${ }^{8}$ por inobservância da normativa paramétrica federal.

A configuração vigente do procedimento analisado, seja com a participação direta do Ministério Público, do Executivo e do Legislativo, seja contando somente com os dois primeiros, constitui, por certo, manifestação do sistema de freios e contrapesos decorrente da experiência brasileira do princípio da separação dos poderes. Neste sentido, ensina Hugo Nigro Mazzilli:

... como sua investidura [do Procurador-Geral de Justiça] supõe um ato composto, o procedimento administrativo não dispensa o concurso de vontades, muito útil num sistema de freios e contrapesos, o que configura mecanismo

\footnotetext{
"A existência de mecanismos de participação dos demais poderes na escolha do chefe da instituição [Ministério Público] representa importante mecanismo integrante do sistema de freios e contrapesos. O que não se entende, todavia, é a razão da diferença dos sistemas federal e estadual de escolha do Procurador Geral: - lista tríplice no âmbito local, sem participação do Legislativo, e participação do Legislativo (Senado) no âmbito Federal, sem prévia elaboração de uma lista tríplice (pelo Ministério Público). Talvez fosse o caso de se somarem os dois sistemas. Em todos os casos, previsão de lista tríplice com aprovação pelo Legislativo (Senado ou Assembléia Legislativa) do nome indicado pelo Chefe do Poder Executivo (Presidente da República ou Governador de Estado). (...) O Constituinte Paranaense foi suficientemente sábio quando (I) exigiu a manifestação da Assembléia Legislativa não apenas no caso de destituição, como, igualmente, no processo de escolha do Procurador Geral de Justiça; (II) quando determinou que, para a formação da lista tríplice, participarão todos os membros do Ministério Público, e não apenas os integrantes de órgãos compostos por membros em final de carreira e (III), também, quando determinou que a recondução poderá ocorrer, desde que, todavia, observado o mesmo processo (lista tríplice, aprovação pelo Legislativo e nomeação pelo Executivo). Previsão como esta deveria constar na Constituição Federal para disciplinar o processo de escolha e nomeação tanto do Procurador Geral da República quanto dos Procuradores Gerais de Justiça." CLÈVE, Clèmerson Merlin, op. cit., p. 108-109.

${ }^{3}$ Cf. ADInMC 2.319-PR: "Por aparente ofensa ao art. 128, §3, da CF ("Os Ministérios Públicos dos Estados e do Distrito Federal e Territórios formarão lista tríplice dentre integrantes da carreira, na forma da lei respectiva, para escolha de seu Procurador-Geral, que será nomeado pelo Chefe do Poder Executivo, para mandato de dois anos, permitida uma recondução."), o Tribunal, julgando medida cautelar em ação direta ajuizada pelo Partido Social Liberal - PSL, deferiu a suspensão cautelar de eficácia de expressão contida na Constituição do Estado do Paraná e de dispositivos da Lei Complementar 85/99, do mesmo Estado, que condicionam a nomeação do Procurador-Geral de Justiça do Estado à prévia aprovação de seu nome pelo Poder Legislativo estadual (expressão "após a aprovação da assembléia legislativa", constante do caput do art. 166 da Constituição do Estado do Paraná; o $\$ 1^{\circ}$ do art. 10 , os $\$ \S 2^{\circ}$ e $3^{\circ}$ do art. 16 e, ainda, no mesmo artigo, a expressão "submetendo-o à aprovação pela Assembléia Legislativa", todos da Lei Complementar Estadual 85/99). Precedentes citados: ADInMC 1.228-AP (DJU, 2 jun. 1995) e ADInMC 1.506-SE (DJU, 21 nov. 1996). ADInMC 2.319-PR, rel. Min. Moreira Alves, 1․8.2001. ADI-2319) Informativo STF, 235.
} 
muito mais seguro para a coletividade. ${ }^{9}$

\section{Sistema de freios e contrapesos}

O conteúdo do princípio da separação de poderes manifesta-se a partir de um dinâmico processo de interpretação indissociável do momento histórico que desafia sua concretização. Assim, na atual configuração, não só comporta como demanda certas interferências consideradas legítimas e necessárias.

Pode-se afirmar, com Carlos Roberto Siqueira Castro que:

a despeito da leitura histórica original que radicalizava a tese separatista, que a convivência política e institucional entre os três Poderes terminou por acatar as práticas mais diversas de mútua colaboração e, especialmente, de recíproco controle entre os órgãos e agentes estatais, isso como exigência incontornável do regime democrático, que, de ordinário, não tolera o absolutismo ou a incontrastabilidade do exercício da autoridade. Nessa ordem de idéias, o sistema de freios e contrapesos ou de controles recíprocos, consoante cunhado pelo constitucionalismo norte-americano na Convenção de Filadélfia em 1787, traduz a pioneira adoção da fórmula de Montesquieu na primeira Constituição formal da era moderna, mas tornando-a permeável, sob o influxo do discurso de inspiração democrática contra o abuso de autoridade, a multiformes mecanismos de controles interórganos, pelos quais cada um dos Poderes do Estado desempenha variados tipos de papel de fiscalizador em face do exercício das competências exercitáveis por parte dos demais Poderes associados. A traduzir essa nova percepção colaboracionista e de interação entre os três poderes, a Constituição brasileira de 1988 não mais consente a ortodoxia separatista, a ponto de haver suprimido a tradicional vedação de indelegabilidade das funções próprias de cada Departamento especializado da soberania, cingindo-se a estatuir, no art. $2^{\circ}$, que "são Poderes da União, independentes e harmônicos entre si, o Legislativo, o Executivo e o Judiciário”.

Ninguém discutirá que o princípio da separação de Poderes segue sendo entre nós, um postulado vetor de nossa organização política, eis que incluído no $\S^{\circ}$ do art. 60 da Constituição dentre as matérias, importando tendência voltada à abolição, insuscetíveis de deliberação por emenda constitucional, designadas de cláusulas pétreas. ${ }^{10}$

Não é o caso, aqui, de aprofundar a idéia segundo a qual, na realidade, não se trata de separação de "poderes" mas sim de "funções" do Estado, muito menos a questão de ser ou não o Ministério Público integrante de um dos Poderes ou um outro distinto. Desde que se entenda ser possível a aplicação do sistema de freios e contrapesos a qualquer

\footnotetext{
9 MAZZILLI, Hugo Nigro. Regime Jurídico do Ministério Público. 5. ed. São Paulo: Saraiva, 2001, p. 239.

${ }^{10}$ SIQUEIRA CASTRO, Carlos Roberto. A Atuação do Tribunal de Contas em face da Separação de Poderes do Estado. Revista de Direito Constitucional e Internacional, n. 31, abr./jun. 2000, p. 62.
} 
das atividades estatais manifestadas por órgãos constitucionais, sejam elas típicas ou não de um Poder, qualquer posicionamento que se adote neste particular permitirá, ainda que por analogia, aplicá-lo na investigação do presente tema. Aceite-se, além do mais, que, se o Ministério Público não constitui Poder, ele se manifesta, também, como órgão constitucional dotado de status constitucional, condição singular que o autoriza a participar, com os Poderes e demais órgãos constitucionais, da dinâmica dos freios e contrapesos delineada na Constituição da República.

A administração da máquina estatal se realiza com a consagração da independência entre os poderes, mas também com a harmonia possível dentro de um sistema de controles recíprocos. Esta realidade requer renovadas medidas conducentes ao equilíbrio almejado, medidas essas nem sempre de fácil aceitação. Na doutrina já se afirmou:

... o grande problema da prática dos regimes são as formas de efetivação da contenção dos poderes estatais entre si, de maneira a conseguir o equilíbrio do Poder. A tendência, na realidade, é de sobrepujança, de liderança de um poder sobre os demais. E a própria aplicação dos freios e contrapesos importa na ingerência de um poder na atividade dos outros, gerando uma colaboração, que é realmente, contrária à sua separação. Por sinal, na prática, é impossível essa separação no sentido de que cada poder trabalhe desvinculado dos demais, posto que, se isso fosse possível, quebrar-se-ia a unidade estatal.

São os poderes do Estado, com efeito, um sistema de vasos comunicantes, e quanto mais houver essa comunicação e essa ajuda mútua, de forma compreensiva e harmônica, melhormente [sic] funcionará o mecanismo estatal, com conseqüências positivas na vida da Nação. ${ }^{11}$

Excluídas as "intromissões" (verdadeiras invasões a campos competenciais reservados), as interferências de um poder sobre outro através de instrumentos constitucionalmente previstos consagra forma de controle que serve para equilibrar a distribuição e exercício de funções. Afirma Anna Cândida da Cunha Ferraz que

quando essa intervenção se debruça sobre a formação de outro Poder (composição do Supremo Tribunal Federal, por exemplo) ou de órgãos que se situam fora do âmbito estrito da atuação da Administração Pública [...], configura-se ela como instrumento próprio de controle político ou ínsito do sistema de freios e contrapesos, propício a conduzir ao equilíbrio e à harmonia entre os Poderes que participam do ato. ${ }^{12}$

\footnotetext{
${ }^{11} \mathrm{OMMATI}$, Fides. Dos Freios e Contrapesos entre os Poderes do Estado. Revista de informação legislativa, n. 55, jul./set. 1977, p. 62.
} 


\section{Forma de escolha da chefia do Ministério Público e independência funcional}

Não há motivo para argumentar com o prejuízo para a autonomia do Ministério Público em virtude da participação de órgão do Executivo na escolha do chefe da instituição local, uma vez que tal participação depende de prévia seleção interna corporis entre os membros da carreira, não maculando a independência funcional ${ }^{13}$ que lhe é garantida. É preciso ter claro que o exercício do poder-dever de nomeação do Procurador-Geral pelo Chefe do Executivo não tem o condão de por si só transmudar os rumos de toda a instituição ministerial para que de "defensora da ordem jurídica" passe a "defensora dos interesses do Governador". Ainda que o oposto fosse verossímil, recaindo sobre o responsável pela chefia da instituição total convergência com os interesses políticos imediatos, suas ações precisariam ultrapassar a inexistência de hierarquia (salvo sob a ótica administrativa) entre os membros do parquet, que "exercem suas atribuições sempre de acordo com a consciência do justo que guardam."14

Deve ser tomada em consideração que as garantias funcionais reconhecidas aos membros do Ministério Público, pela Constituição e pela lei, o foram exatamente para que pudessem servir aos interesses da Lei e não aos dos governos ou governantes. Entretanto, é evidente que, no tocante a medidas administrativas, devem os membros da Instituição acatar as decisões dos órgãos da Administração Superior do Ministério Público, tais como a imposição de medidas disciplinares, a solução dos conflitos de atribuições e até mesmo as que optam pela revisão de uma promoção de arquivamento de inquérito, tanto civil como criminal, que, embora não se contenha na esfera administrativa da Instituição, é atribuição específica de sua Administração Superior. O que não se pode, contudo, admitir é a imposição a um membro do Ministério Público, no exercício de suas funções, por órgão da Administração Superior ou qualquer outra autoridade estatal, de um comportamento em relação à determinada matéria cuja solução dependa de sua convicção. ${ }^{15}$

Reputa-se a independência funcional como sendo um dos maiores trunfos dos membros do Ministério Público para o exercício de suas funções

\footnotetext{
2 FERRAZ, Anna Cândida da Cunha. Conflito entre Poderes: o Poder Congressual de Sustar Atos Normativos do Poder Executivo. São Paulo: Revista dos Tribunais, 1994, p. 26.

13 "Ser independente significa, em primeiro lugar, que cada um de seus membros age segundo sua própria consciência jurídica, com submissão exclusivamente ao direito, sem ingerência do Poder Executivo, nem dos juízes e nem dos órgãos superiores do próprio Ministério Público." CINTRA, Antônio Carlos de Araújo et al. Teoria Geral do Processo. 17. ed. São Paulo: Malheiros, 2001, p. 213.

${ }^{14}$ CLÈVE, op. cit., p. 104.

${ }^{15}$ SAUWEN FILHO, João Francisco. Ministério Público Brasileiro e o Estado Democrático de Direito. Rio de Janeiro: Renovar, 1999, p. 212-213.
} 
com imunidade de pressões políticas, porém, pouco se fala das limitações a este postulado. De fato, tal conquista foi positivada de modo inquestionável pelo Constituinte de 1988 para compor o sistema constitucional e não para sustentar uma interpretação isolada, eventualmente corporativa. Neste sentido, bem ensina Hugo Nigro Mazzili que:

Se fosse absolutamente ilimitada a independência funcional, também seria ilimitada a possibilidade de abuso. Em si mesma a liberdade, um dos postulados básicos da democracia, sujeita-se também a limites previstos em lei. Não fosse assim, sob o manto da liberdade e da independência funcional, o Promotor ou o Juiz poderiam arbitrariamente negar cumprimento à própria Constituição Federal, que é o fundamento não só da ordem jurídica como até mesmo de suas investiduras; ou então poderiam sustentar, sem a menor razoabilidade, apenas fundados em abstrações ou especulações genéricas, qualquer quebra da ordem jurídica. ${ }^{16}$

\section{Lembre-se ainda o seguinte:}

... o Chefe do Executivo (e, portanto, todos os seus subordinados) não pode atentar contra o "livre exercício do Ministério Público", sob pena de incidir em crime de responsabilidade (art. 85, II). Tanto é assim que ele detém autonomia administrativa, autogoverno, e, portanto, não sujeito ao autogoverno do Executivo e à sua "direção superior" prevista no art. 84, II.

Poder-se-ia dizer, neste passo, que a situação não é bem assim porque ao Chefe do Executivo cabe nomear o Procurador-Geral da República, na União, ou o Procurador-Geral de Justiça, nos Estados e no Distrito Federal. A objeção seria descabida, uma vez que a ele também cabe nomear os Ministros do Supremo Federal e dos Tribunais Superiores, sem que isso quebre a independência da função jurisdicional.

Ademais, se a ele cabe nomear, com aprovação do Senado federal, o Procurador-Geral da República, por outro lado, não pode exonerá-lo livremente antes do término do mandato de dois anos previsto no art. $128, \S 1^{\circ}$, uma vez que só poderá fazê-lo previamente autorizado pelo Senado Federal (art. 128, $\S 3^{\circ}$ ), e nos Estados e Distrito Federal nem mesmo essa competência tem o Chefe do Executivo, pois o Procurador-Geral de Justiça só pode ser destituído, antes do término do mandato, "por deliberação da maioria absoluta do Poder Legislativo" (art. 128, $\S^{\circ}$ ).

Como se vê, a nomeação do Procurador-Geral pelo Executivo, ao lado da autorização para a sua destituição ou a própria destituição pelo Legislativo, nada mais representa daquilo já existente entre as funções independentes do Legislativo, do Judiciário e do Executivo: a fórmula de "freios e contrapesos", de todos conhecida. ${ }^{17}$

A investidura do Procurador-Geral de Justiça advinda de ato com-

\footnotetext{
${ }^{16}$ MAZZILI, Hugo Nigro. Os Limites da Independência Funcional no Ministério Público. Revista dos Tribunais, n. 715 , maio 1995 , p. 572-573
}

A \& C R. de Dir. Administrativo e Constitucional, Belo Horizonte, ano 5, n. 19, p. 55-71, jan./mar. 2005 
posto, ainda que sujeita a críticas dos que entendem haver aí ingerência política, presta-se também para prevenir eventual cegueira institucional muitas vezes decorrente de um olhar corporativo sobre o mundo, situação em que a lógica política interna corporis da instituição (democracia interna) poderia desencadear práticas em desacordo com a democracia externa que deve prevalecer. ${ }^{18} \mathrm{~A}$ democracia republicana não é a democracia das corporações, como se sabe. O cargo de Procurador-Geral de Justiça importa para toda a república, para toda a coletividade federada, e não apenas para aqueles que exercem a função ministerial.

Vale, neste ponto, transcrever o alerta de Ricardo Sampaio:

...os membros do Ministério Público não podem prescindir da obediência aos princípios constitucionais, legais e morais, sob pena de estragarem a instituição com o corporativismo e o fisiologismo, tão condenáveis em outras instituições brasileiras.

Os homens e mulheres de bem, que são a vasta maioria deste excepcional órgão em que se transformou o Ministério Público, e principalmente os que não incorporam quaisquer vantagens sem causa, têm o dever de atuar. Têm o dever de zelar pelo prestígio da instituição que não é sua, é do povo brasileiro. ${ }^{19}$

Não se pode ignorar que, enquanto seres humanos dotados de personalidade própria, pode haver (e certamente haverá) dentre os eleitos pela instituição ministerial, aqueles que comungam de certos posicionamentos políticos (no melhor sentido da expressão) adotados por este ou aquele governo. Talvez fosse crível forçar os candidatos a ProcuradorGeral a se despirem de toda carga valorativa pessoal antes da participação no pleito; porém, um ensaio deste naipe não representaria mais do que esforço inútil, à semelhança daquele necessário para justificar o compromisso impossível com o requisito da neutralidade axiológica para o exercício da jurisdição.

\footnotetext{
${ }^{17}$ BURLE FILHO, José Emmanuel. O Ministério Público e sua Posição Constitucional. Revista de Informação Legislativa, n. 103, jul./set. 1989, p. 246.

18 Há aqueles, como Marcelo Pedroso Goulart, que sustentam a necessidade da "criação de mecanismos de controle da instituição pela sociedade civil, para que os seus membros, em especial aqueles que ocupam cargos nos órgãos de direção interna, não se percam no corporativismo e não desviem o Ministério Público dos objetivos institucionais determinados pela Constituição". Para Hugo Nigro Mazzili, o risco de corporativismo configurar-se-ia "tão mais sério quando eventualmente advenha de lege ferenda, a possibilidade de a própria instituição escolher seu procurador-geral, sem a participação dos governantes." In: MAZZILLI, Hugo Nigro. O Acesso à Justiça e o Ministério Público. São Paulo: Saraiva, 1998, p. 46.

${ }^{19}$ SAMPAIO, Ricardo. O Ministério Público e a Sujeição à Lei e à Moral. Revista dos Tribunais, n. 720, out. 1995, p. 362.
} 


\section{Entretanto,}

O Ministério Público, num contexto democrático social atual, não pode mais ser concebido como simples órgão de colaboração do governo, com a finalidade de coadjuvá-lo enquanto organização política - como ocorria nos Estados fundados na hipertrofia inspiradora dos regimes fascistas da primeira metade do atual século -, ou mecanismo de defesa de seus interesses, mas se define cada vez mais como instrumento de tutela de direitos e interesses sociais e legítimas liberdades, para a realização dos ideais democráticos nos justos limites dos princípios consagrados nas modernas democracias sociais contemporâneas.

A eficiência da instituição na realização desses valores e os benefícios prestados ao cidadão na busca da realização de seus ideais em sociedade, como membro do corpo cívico da nação, constituem-se não só a finalidade precípua da instituição, enquanto mecanismo de defesa da sociedade, como ainda a sua razão de ser e condição de permanência no universo de órgãos públicos.

Ora, para atingir tais metas, uma instituição terá que dispor de quadros adequadamente preparados para o desempenho das funções que lhe forem confiadas. ${ }^{20}$

\section{É pertinente transcrever importante manifestação de Hugo Nigro}

Mazzili:

O sistema atualmente em vigor para escolha de chefe do Ministério Público contempla uma forma de democracia indireta porque a legitimação decorre da eleição democrática do titular da escolha (escolha do Procurador-Geral pelo Chefe do Executivo); ao mesmo tempo, na esfera estadual, assegura-se a participação da classe (corporação) na elaboração da lista tríplice, enquanto, na esfera federal, assegura-se a participação de uma assembléia de origem eletiva, que tem o direito de veto à escolha do Procurador-Geral da República. Assim, no sistema vigente, o eventual corporativismo é mitigado pela interferência externa na escolha; e, reciprocamente, ao menos no tocante à investidura dos Procuradores-Gerais de Justiça dos Estados, as eventuais influências externas em sua escolha podem ser mitigadas pela classe, que tem o poder de formar livremente a lista tríplice que limita o rol entre os quais o governador pode escolher seu preferido. ${ }^{21}$

\section{O papel do chefe do executivo}

Divergências ideológicas a parte, o Governador do Estado tem assegurada constitucionalmente a prerrogativa de escolher um entre três candidatos indicados pelos membros da instituição ministerial para o cargo de Procurador-Geral de Justiça. Eventual tentativa de compressão

\footnotetext{
20 SAUWEN FILHO, op. cit., p. 230.

${ }^{21}$ MAZZILLI, Hugo Nigro. O Acesso..., p. 161.
}

A \& C R. de Dir. Administrativo e Constitucional, Belo Horizonte, ano 5, n. 19, p. 55-71, jan./mar. 2005 
ou limitação da extensão do ato decisório pode implicar atentado a (ou expropriação de) competência constitucionalmente deferida.

O eventual mau uso da competência pelo Executivo constitui, é certo, um risco inerente ao dinâmico processo democrático por ser este construído por seres humanos falíveis, integrantes de uma sociedade plural, mas não é suficiente para servir de argumento para a inobservância da construção normativa residente na Constituição.

Assim como os membros da instituição ministerial podem, legitimamente, compor a lista tríplice, o Governador do Estado está autorizado a escolher um dentre eles, não necessariamente o mais votado. Compõe, este último, ato discricionário ${ }^{22}$ juridicamente legitimado que só se realiza à vista da manufatura da lista (com seu conseqüente encaminhamento), lista obrigatoriamente tríplice, reitere-se.

Em julgamento de Embargos Infringentes opostos contra Acórdão prolatado pelo Supremo Tribunal Federal na ADIn 1289-DF em que se discutia a inclusão de membros do Ministério Público que não preencheram o requisito da antigüidade na lista sêxtupla para formação do quinto constitucional, foi a seguinte manifestação da Procuradoria-Geral da República:

A Constituição exige, de fato, para a formação do quinto constitucional, a elaboração de lista sêxtupla com os membros do Ministério Público que possuam mais de dez anos de carreira. Porém, nada dispõe a Carta da República na hipótese de faltarem membros do Ministério Público que possuam aquele requisito temporal de dez anos de carreira para compor a necessária lista sêxtupla.

Assim sendo, se não há vedação constitucional expressa, afigura-se legítima a complementação da lista sêxtupla com membros do Ministério Público que, embora tenham sido submetidos ao processo de escolha comum a todos os candidatos, não tenham completado, ainda, o período de dez anos a que se refere o art. 94 da Constituição da República.

Ademais, como afirmado nos embargos, "a lista sêxtupla" visa a permitir a possibilidade de escolha pelo Poder Judiciário de três nomes entre os seis candidatos,

\footnotetext{
22 "Poder Discricionário não é arbítrio pessoal da autoridade. Jamais é possível, legalmente, arbítrio pessoal: haverá sempre uma vinculação legal do ato administrativo à competência do seu autor, assim como à qualificação do seu motivo, do seu objetivo e do fim de interesse público a que ele deva prover. Não é só a liberdade de agir, própria de todo titular, sujeito de um direito, ou poder: no Direito Administrativo, não existe a 'autonomia da vontade', peculiar do direito privado. Neste, as pessoas atuam em razão dos seus próprios interesses, desde que não sejam ilícitos. Enquanto isto, o poder da autoridade é um dever de decidir, nunca em seu proveito pessoal, mas sempre em razão de um motivo definido em lei e para o fim de interesse público, a que, ainda de acordo com essa lei, o efeito prático de sua ação deva corresponder." PONDÉ, Lafayette. Controle dos Atos da Administração Pública. Revista de Informação Legislativa, n. 138, jul./set. 1998, p. 136.
} 
bem assim, posteriormente, a escolha pelo Poder Executivo de um único nome entre aqueles constantes da lista tríplice elaborada pelo Poder Judiciário. Portanto, a formação, pelo órgão de classe, de uma lista em número inferior a seis representaria cerceamento tanto no dever-poder atribuído ao Poder Judiciário de, dentre seis nomes, escolher três, como também no dever-poder do Poder Executivo de escolher apenas um. (g. n.)

Com efeito, veja-se que, na hipótese de haver apenas um candidato com mais de dez anos de carreira, teria ele verdadeiro direito subjetivo à sua nomeação, restando tolhida a necessária participação dos Poderes Judiciário e Executivo no processo de preenchimento do quinto constitucional, contrariando, dessa forma, a Constituição Federal.

A situação relatada guarda pertinência com o objeto do presente artigo, calhando a citação de importante parte do voto do Min. Gilmar Ferreira Mendes:

Ademais, cumpre observar que, ao consagrar o critério da lista sêxtupla composta por procuradores que ainda não preenchiam o requisito temporal, no caso de falta de membros habilitados, a resolução referida atendeu a um outro valor, igualmente importante para o texto constitucional: o respeito à liberdade de escolha por parte do Tribunal e do próprio Poder Executivo. Do contrário, restaria prejudicado o equilíbrio que o texto constitucional pretendeu formular para o sistema de escolha: participação da classe na formação da lista sêxtupla; participação do Tribunal na escolha da lista tríplice e participação do Executivo na escolha de um dos nomes. A formação incompleta da lista sêxtupla ou até mesmo o envio de um ou dois nomes que preenchessem todos os requisitos constitucionais acabaria por afetar o modelo original concebido pelo constituinte, reduzindo ou eliminando a participação do Tribunal e do Executivo no processo de escolha. (g. n.)

(...)

Muito mais distante da vontade constitucional seria a composição do Tribunal sem a participação dos integrantes do Ministério Público, significa dizer, sem a observância do princípio do quinto constitucional na espécie. Da mesma forma, haveria de revelar-se distante do texto constitucional a composição da lista com número inferior ao estabelecido constitucionalmente, afetando o modelo já restrito de liberdade de escolha. (g. n. $)^{23}$

Ressalte-se que o Ministério Público é uma instituição incumbida da defesa da ordem jurídica, do regime democrático e dos interesses sociais e individuais indisponíveis. É evidente que a função de defesa do regime democrático haverá de exigir uma interpretação adequada das regras atinentes à escolha da chefia da instituição ministerial. Interpretação que implica a manifestação da ação necessária para a composição da lista. A

\footnotetext{
${ }^{23}$ Infere-se posicionamento alinhado também no Superior Tribunal de Justiça, em julgamento de recurso em Mandado de Segurança de n. ${ }^{\circ}$ 4.158-RS para promoção de magistrado por merecimento. É a
} 
autonomia da instituição, conferida pela Constituição, trouxe consigo o ônus da composição da lista tríplice. Qualquer desconforto interno quanto à participação do Poder Executivo no processo de escolha do Procurador Geral deve, por isso mesmo, ser resolvido dentro do marco constitucional e sem expedientes voltados ao enfraquecimento da competência conferida ao Executivo. Está-se, aqui, a falar, portanto, em colaboração necessária entre órgãos constitucionais (Executivo e Ministério Público) para a nomeação do Chefe da instituição ministerial.

Nomeado pelo Governador do Estado, nem por isso o Procurador Geral haverá de desenvolver comprometimento com a cosmovisão de quem o nomeou. Afinal,

A lealdade dos agentes das procuraturas constitucionais não se dirige aos Governos mas à ordem jurídica a que todos devem servir com elevação e independência: por isso têm o poder de impulso, do qual não se devem demitir, nem mesmo por receio de desagradar aos agentes de quaisquer dos Poderes, ainda que o Chefe do Poder Executivo, que nomeia os Chefes institucionais das procuraturas constitucionais. ${ }^{24}$

\section{Defesa da Constituição e devida composição da lista tríplice}

Neste ponto, não seria demais considerar algumas hipóteses dotadas de relevância prática. Entre elas, o caso de ser encaminhado ao Governador apenas o nome do mais votado dentre os candidatos a Procurador-Geral de Justiça, e o caso de haver menos de três candidatos no processo eleitoral interno promovido pela instituição ministerial.

O encaminhamento de expediente abrigando apenas o nome do mais votado em eleição com ao menos três candidatos não parece guardar sintonia com o modelo de investidura do Chefe do Ministério Público adotado pelo Constituinte. Afinal, como antes referido, cabe ao Governador do Estado escolher um dentre os três nomes encaminhados pelo Ministério Público Estadual, seja ele o mais votado, ou não. Este é o arranjo constitucional atualmente em vigor. Daí porque não está, por outro lado, o Governador (do ponto de vista jurídico) vinculado ao nome mais prestigiado, do ponto de vista do sucesso eleitoral, da lista tríplice. Pode constituir gesto de

ementa: "Lista tríplice. Correto o critério de inclusão de outros juízes para integração da primeira quinta parte da lista de antigüidade, em substituição aos que tenham recusado a vaga (CF, art. 93, II, b), incorreta, porém, resulta a indicação por escolha de apenas um concorrente dentre aqueles supletivamente incluídos; isso, em condenável detrimento do remanescente da primitiva quinta parte, único plenamente habilitado a concorrer à lista tríplice injustificadamente olvidada." RSTJ, n. 94, jun. 1997, p. 293.

${ }^{24}$ MOREIRA NETO, Diogo de Figueiredo. As Funções Essenciais à Justiça e as Procuraturas Constitucionais. Revista de Informação Legislativa, n. 116, out./dez. 1992, p. 95. 
sabedoria política o indicar o nome mais votado. Mas incumbe à instituição compor a lista tríplice, constituindo atribuição do Chefe do Executivo escolher, livremente, o novo Procurador Geral de Justiça. Ficasse o Governador vinculado ao nome mais votado, e estaríamos em verdade desenhando outro modelo, no qual os eleitores da instituição escolhem o novo Chefe que o Governador, com poder decisório equivalente ao decorrente do exercício de função meramente protocolar, nomeia. Semelhante interpretação, do ponto de vista jurídico, não se concilia com as conseqüências do modelo presidencial adotado pela Constituição de 1988.

A segunda hipótese requer certa dose de cuidado. Se, numa situação extraordinária, dentre os inúmeros membros da carreira, somente dois concorrem à formação da lista, manifesta-se impossibilidade fática de apresentação da lista tal como exigida pela normativa constitucional. Diante de um quadro assim, poder-se-ia adotar, a fim de se cumprir o ditame legal e enquanto medida extrema, uma lista dúplice a ser encaminhada ao Governador do Estado. Primeiro cumpre ressaltar ser indispensável a realização do processo eleitoral no seio da instituição ministerial, respeitandose as diretivas legais para sua devida realização. Quanto a esta questão não deve haver divergência, pois a eleição pelos membros da carreira tem sido a bandeira levantada, inclusive, por aqueles que discordam da participação de órgãos externos no procedimento de investidura do Procurador Geral. Efetivando-se a eleição e daí resultando apenas dois nomes para a lista, a solução para esta situação incomum exigirá certa dose de cuidado.

Constitui dever indeclinável da instituição o desenvolvimento dos esforços indispensáveis para a satisfação da exigência constitucional, estimulando, inclusive, a pluralidade de postulações no processo eleitoral interno. É o que, em princípio, haverá de ocorrer. Até porque não é crível que, numa instituição composta, em geral, por centenas de membros, não se manifeste disputa para um cargo de singular importância. Certamente, salvo a hipótese de compressão das possibilidades de apresentação de candidaturas ou do ambiente favorável ao exercício da democracia interna, mais de três candidatos apresentar-se-iam. De qualquer forma, há que se considerar a hipótese outra. Neste caso, a diretiva constitucional de formação de lista tríplice esbarra na excepcionalidade da situação.

Ora, não havendo possibilidade fática de formação de lista tríplice, o encaminhamento de lista menor poderia atender, em determinada circunstância, a exigência constitucional por permitir que o Chefe do Executivo exerça minimamente seu poder decisório. Poder-se-ia, A \& C R. de Dir. Administrativo e Constitucional, Belo Horizonte, ano 5, n. 19, p. 55-71, jan./mar. 2005 
eventualmente, cogitar da complementação da lista com candidato alheio ao pleito promovido pela instituição. Tal medida seria descabida por ferir a prerrogativa dos membros do Ministério Público participarem da eleição do Procurador-Geral. Poder-se-ia, também, propor a prorrogação do tempo de investidura do Procurador-Geral em exercício, mas semelhante medida igualmente seria inaceitável por ferir norma constitucional definidora do tempo exercício do cargo. Tais hipóteses agridem com maior gravidade a Constituição que a admissão, em circunstância absolutamente singular, lista composta por dois nomes. Por exclusão, é de admitir-se, então, a excepcional possibilidade de apresentação de lista dúplice ao Governador como medida suscetível de ser tolerada. A uma por atender minimamente a finalidade da formação de uma lista tríplice; a duas por ter conseqüências menos danosas que outras medidas possíveis; a três por distribuir o ônus do não cumprimento integral do procedimento positivado entre aqueles diretamente relacionados a ele. A situação, entretanto, exigirá negociação entre os órgãos constitucionais. Mais do que isso, apresentação de lista não satisfatória deve vir acompanhada das razões que justificam-na. Razões suficientemente graves para autorizar a excepcionalidade da medida.

É preciso ter em mente que, ainda que a candidatura configure, desde um ponto de vista pessoal, direito do promotor ou procurador, trata-se, por outro lado, de manifestação democrática cara à instituição e, portanto, de um direito cujo exercício deve ser suficientemente fomentado. Daí porque, constituindo direito para o membro do parquet, substancia dever indeclinável para a instituição em função do arranjo constitucional.

Para melhor ilustrar a necessidade de adoção de medida incomum, mas razoável, diante da impossibilidade de cumprimento integral do programa normativo positivado, calha citar a célebre manifestação do Procurador-Geral Terlinden por ocasião do julgamento, na Corte de Cassação da Bélgica, de caso que envolvia o exercício solitário, pelo Rei, da função legislativa, contrariando diretiva constitucional, durante a ocupação alemã, por ocasião do último conflito mundial:

Uma lei - constituição ou lei ordinária - nunca estatui senão para períodos normais, para aqueles que ela pode prever.

Obra do homem, ela está sujeita, como todas as coisas humanas, à força dos acontecimentos, à força maior, à necessidade.

Ora, há fatos que a sabedoria humana não pode prever, situações que não pôde levar em consideração e nas quais, tornando-se inaplicável a norma, é necessário, de um modo ou de outro, afastando-se o menos possível das prescrições legais, fazer frente às brutais necessidades do momento e opor meios provisórios à força invencível dos acontecimentos. ${ }^{25}$

A \& C R. de Dir. Administrativo e Constitucional, Belo Horizonte, ano 5, n. 19, p. 55-71, jan./mar. 2005 
O sistema de freios e contrapesos, importa realçar, exige a apresentação de lista composta por três nomes. A relação entre os poderes deve ser presidida pelo dever de colaboração, cooperação e boa fé, que decorrem da idéia constitucional de harmonia entre os órgãos integrantes do sistema de freio e contrapesos. O não estimular a formação de lista tríplice ou o apresentar lista sem o número constitucionalmente exigido de nomes, pode sugerir afronta não apenas à competência do Chefe do Executivo, como também ao princípio da separação de poderes. Reiterese, portanto, que a apresentação de lista insatisfatória somente pode ser aceita em situação de extremada singularidade, em hipótese de excepcionalidade absoluta, que deve ser justificada pelas circunstâncias e, mais do que isso, suficientemente motivada. Neste caso, como o direito não pode disciplinar o impossível nem exigir o que não se pode dar, os órgãos constitucionais haverão de chegar a uma situação de solução particularizada. Fora daqui, entretanto, eventual lista insuficiente haverá de ser tida como eivada de vício, inválida mesmo, podendo até, no limite, ser devolvida ao Ministério Público pelo Governador para que este a complete, inclusive, se for o caso, promovendo nova eleição.

Interesses tocados pela lógica interna da instituição, ainda que orientados pela boa intenção e voltados à defesa da "democracia corporativa" não podem contrariar interesses maiores, dentre os quais o de concretização da Constituição, este sim, especialmente no caso brasileiro, alinhado com um histórico processo de democratização republicana. Vale lembrar que, após a alternância de regimes ditatoriais e incipientes movimentos democráticos, a Constituição brasileira de 1988 bem definiu em seu artigo 127, caput, o Ministério Público como instituição permanente à qual, dentre outras relevantes atribuições, insere-se a defesa do regime democrático. ${ }^{26}$ Não seria sábio, por isso, fechar a instituição em si mesma, distanciando-a dos jogos políticos existentes no inacabado projeto de democratização do país, já que eles servem de provação para a demonstração da verdadeira vocação que aos seus membros acomete.

\section{Conclusão}

Nos termos da Constituição em vigor e da legislação de regência da matéria, é obrigatório o encaminhamento, pelo Ministério Publico Estadual,

\footnotetext{
${ }^{25}$ Citado por PERELMAN, Chaïm. Lógica Jurídica. Trad. Vergínia K. Pupi. São Paulo: Martins Fontes, 1998, p. 106.
}

A \& C R. de Dir. Administrativo e Constitucional, Belo Horizonte, ano 5, n. 19, p. 55-71, jan./mar. 2005 
ao Governador do Estado, de lista contemplando três nomes apurados em eleição interna para a escolha do Procurador-Geral de Justiça.

Consagrou-se um processo bifásico de escolha do Procurador-Geral de Justiça em que há participação dos membros do Ministério Público elegendo seus candidatos que formarão lista tríplice a partir da qual se dará a participação do Chefe do Executivo, complementando o modelo integrante do sistema constitucional de freios e contrapesos.

Informação bibliográfica deste texto, conforme a NBR 6023:2002 da Associação Brasileira de Normas Técnicas (ABNT):

CLÈVE, Clèmerson Merlin; MARTINS, Alessandra Ferreira. A Constituição e os requisitos para a investidura do Chefe do Ministério Público nos Estados. A $\mathcal{E}^{2} C$ Revista de Direito Administrativo e Constitucional, Belo Horizonte, ano 5, n. 19, p. 55-71, jan./mar. 2005.

\footnotetext{
26 "...o Ministério Público pode existir seja num regime autoritário, seja num regime democrático; poderá ser forte tanto num, quanto noutro caso; porém, só será verdadeiramente independente num regime essencialmente democrático, porque não convém a governo totalitário algum que haja uma instituição, ainda que do próprio Estado, que possa tomar, com liberdade total, a decisão de acusar governantes ou de não processar os inimigos destes últimos." MAZZILI, Hugo Nigro. O Ministério Público e a defesa do regime democrático. Revista de Informação Legislativa, n. 138, abr./jun. 1998, p. 66.
} 